\title{
Heterostructured BiOI@La(OH) 3 nanorods with enhanced visible light photocatalytic NO removal
}

\author{
Yanjuan Sun a, Xiang Xiao a , Xing'an Dong a, Fan Dong a,*, Wei Zhang b,\# \\ a Chongqing Key Laboratory of Catalysis and New Environmental Materials, Engineering Research Center for Waste Oil Recovery Technology and \\ Equipment of Ministry of Education, College of Environment and Resources, Chongqing Technology and Business University, Chongqing 400067, China \\ b Chongqing Institute of Green and Intelligent Technology, Chinese Academy of Sciences, Chongqing 400714, China
}

\section{A R T I C L E I N F}

\section{Article history:}

Received 28 September 2016

Accepted 14 November 2016

Published 5 February 2017

\section{Keywords:}

Bismuth oxyiodido@lanthanide

hydroxide heterostructure

Nanorod

Photocatalysis

Visible light

Nitrogen oxide removal

\begin{abstract}
A B S T R A C T
Heterostructured BiOI@La(OH) $)_{3}$ nanorod photocatalysts were prepared by a facile chemical impregnation method. The enhanced visible light absorption and charge carrier separation can be simultaneously realized after the introduction of $\mathrm{BiOI}$ particles into $\mathrm{La}(\mathrm{OH})_{3}$ nanorods. The BiOI@La(OH $)_{3}$ composites were applied for visible light photocatalytic oxidization of NO in air and exhibited an enhanced activity compared with $\mathrm{BiOI}$ and pure $\mathrm{La}(\mathrm{OH})_{3}$ nanorods. The results show that the energy levels between the $\mathrm{La}(\mathrm{OH})_{3}$ and $\mathrm{BiOI}$ phases matched well with each other, thus forming a heterojunctioned BiOI@La(OH) 3 structure. This band structure matching could promote the separation and transfer of photoinduced electron-hole pairs at the interface, resulting in enhanced photocatalytic performance under visible light irradiation. The photocatalytic performance of BiOI@ $\mathrm{La}(\mathrm{OH})_{3}$ is shown to be dependent on the mass ratio of BiOI to $\mathrm{La}(\mathrm{OH})_{3}$. The highest photocatalytic performance can be achieved when the mass ratio of $\mathrm{BiOI}$ to $\mathrm{La}(\mathrm{OH})_{3}$ is controlled at 1.5. A further increase of the mass ratio of BiOI weakened the redox abilities of the photogenerated charge carriers. A new photocatalytic mechanism for BiOI@ $\mathrm{La}(\mathrm{OH})_{3}$ heterostructures is proposed, which is directly related to the efficient separation of photogenerated charge carriers by the heterojunction. Importantly, the as-prepared $\mathrm{BiOI} @ \mathrm{La}(\mathrm{OH})_{3}$ heterostructures exhibited a high photochemical stability after multiple reaction runs. Our findings demonstrate that BiOI is an effective component for the formation of a heterostructure with the properties of a wide bandgap semiconductor, which is of great importance for extending the light absorption and photocatalytic activity of wide bandgap semiconductors into visible light region.
\end{abstract}

(C) 2017, Dalian Institute of Chemical Physics, Chinese Academy of Sciences. Published by Elsevier B.V. All rights reserved.

\section{Introduction}

Since the first report on water splitting with a $\mathrm{TiO}_{2}$ photoelectrode, semiconductor photocatalysis has received attention for application in solar energy conversion and the removal of pollutants [1-8]. Currently, the photocatalytic efficiency for most semiconductors is not sufficient for practical application, especially with the use of visible light from the sun [2-4]. The charge separation and visible light absorption are the most important factors to be considered in the development of effec-

\footnotetext{
* Corresponding author. Tel/Fax: +86-23-62769785; E-mail: dfctbu@126.com

\# Corresponding author. E-mail: andyzhangwei@163.com

This work was supported by the National Key Research and Development Project (2016YFC0204702), the National Natural Science Foundation of China $(51478070,21501016,51108487)$, the Innovative Research Team of Chongqing (CXTDG201602014), the Natural Science Foundation of Chongqing (cstc2016jcyjA0481), and Youth Innovation Promotion Association of Chinese Academy of Sciences (2015316).

DOI: 10.1016/S1872-2067(17)62753-0 | http://www.sciencedirect.com/science/journal/18722067 | Chin. J. Catal., Vol. 38, No. 2, February 2017
} 
tive semiconductor photocatalysts. Various strategies have been applied to tackle these issues, such as doping with heteroatoms, formation of a heterostructure, microstructure optimization and development of new types of photocatalysts [2-6]. Among the plentiful semiconductor materials, one-dimensional (1D) lanthanide hydroxide $\left(\mathrm{La}(\mathrm{OH})_{3}\right)$ nanorods have been receiving increased interest owing to their unique electronic structure and multifunctional properties, especially as an emergent semiconductor photocatalyst [9-11]. However, for a photocatalytic application, the intrinsic wide bandgap of $\mathrm{La}(\mathrm{OH})_{3}$ allows only a small portion of absorption in the ultraviolet (UV) light region of the solar spectra. The relatively low photocatalytic efficiency and visible light use hinder its practical application. To take full advantage of sunlight, it is imperative to extend the light absorption spectra of $\mathrm{La}(\mathrm{OH})_{3}$ into the visible light region. Fortunately, hybrid photocatalysts, generally comprising two or more active components, have been developed to address this issue. These hybrid photocatalysts could integrate the synergistic effects of the active components, which may provide the feasibility and versatility to optimize their optical and photocatalytic performance [12-14].

The coupling of two different semiconductors could enhance the transfer of electrons from an excited small band gap semiconductor into another one that is attached in the case of proper band structure matching. This favors the charge carrier separation and thus improves the photocatalytic efficiency. To obtain the desirable heterostructured photocatalysts, two key factors must be considered. One is the interface lattice matching to form a stable heterostructure. The other is the matching of energy levels between the two components so as to promote charge carrier separation. That is, the conduction band minimum (CBM) of the narrow bandgap semiconductor should be higher than the other component with a lower CB $[15,16]$. In particular, bismuth oxyiodide (BiOI) is an attractive p-type semiconductor with a narrow band gap $\left(E_{\mathrm{g}}=1.70-2.0 \mathrm{eV}\right)$, which means that it exhibits a strong absorption of visible light [17-20]. As a typical p-type semiconductor, BiOI can serve as an effective visible light photosensitizer for semiconductors with a large band gap [21,22]. Therefore, BiOI is a good candidate for coupling with $\mathrm{La}(\mathrm{OH})_{3}$ to form a BiOI@La(OH) 3 heterostructure with a potentially high visible light photocatalytic activity.

We have developed novel heterostructured BiOI@La(OH) nanorods by a facile method. The introduction of BiOI particles into the $\mathrm{La}(\mathrm{OH})_{3}$ nanorods was achieved with a facile impregnation method under mild conditions. The BiOI@ $\mathrm{La}(\mathrm{OH})_{3}$ heterostructures exhibited an enhanced visible light photocatalytic activity towards NO removal compared with $\mathrm{BiOI}$ and $\mathrm{La}(\mathrm{OH})_{3}$ alone. The enhanced activity can be ascribed to the highly enhanced visible light absorption owing to the strong interfacial interactions existing in these components, and the significantly improved charge separation and migration. Meanwhile, the effects of BiOI content on the photocatalytic activity of Bi$\mathrm{OI} @ \mathrm{La}(\mathrm{OH})_{3}$ catalysts were investigated. The BiOI@La(OH) 3 composites exhibited the highest photocatalytic activity when the mass ratio of BiOI@La(OH) 3 was 150\%. More importantly, this excellent photocatalyst showed high photochemical stabil- ity and durability, which is significant for its practical application. The possible photocatalysis mechanism of the Bi$\mathrm{OI} \mathrm{La}(\mathrm{OH})_{3}$ heterojunction is proposed, which could provide new insight into the modification of wide bandgap semiconductors for efficient visible light photocatalysis.

\section{Experimental}

\subsection{Synthesis of $\mathrm{La}(\mathrm{OH})_{3}$ nanorods}

All the chemicals used were of analytical grade and used without further purification. In a typical synthesis, an appropriate amount of $\mathrm{La}\left(\mathrm{NO}_{3}\right)_{3} \cdot 6 \mathrm{H}_{2} \mathrm{O}(1.083 \mathrm{~g})$ was dissolved in distilled water $(30 \mathrm{~mL})$ with continuous stirring. Then, a concentrated ammonia solution $(28 \mathrm{wt} \%, 20 \mathrm{~mL})$ was added with magnetic stirring. Distilled water was added to the above solution, to make a total volume of $70 \mathrm{~mL}$, which was stirred for 30 min. Subsequently, the obtained suspension was transferred to a $100 \mathrm{~mL}$ Teflon-lined autoclave. The precursor solution was hydrothermally treated at $180{ }^{\circ} \mathrm{C}$ for $8 \mathrm{~h}$. After the hydrothermal reaction, the product was centrifuged and washed with distilled water and ethanol four times and dried at $60{ }^{\circ} \mathrm{C}$ to obtain the $\mathrm{La}(\mathrm{OH})_{3}$ nanorods.

\subsection{Construction of BiOI/La(OH) 3 heterostructures}

In a typical process, $\mathrm{La}(\mathrm{OH})_{3}(0.54 \mathrm{~g})$ was added into distilled water $(50 \mathrm{~mL})$ containing a stoichiometric amount of $\mathrm{KI}$, and then dispersed for $30 \mathrm{~min}$ with ultrasound treatment (marked as suspension A). Subsequently, $\mathrm{Bi}\left(\mathrm{NO}_{3}\right)_{3} \cdot 5 \mathrm{H}_{2} \mathrm{O}$ was dissolved into distilled water $(50 \mathrm{~mL})$ with acetic acid $(5 \mathrm{~mL}$; marked as solution B). Then, solution B was added dropwise into suspension A with magnetic stirring for $30 \mathrm{~min}$. The resulting precipitates were collected and washed with water and ethanol four times, and dried at $60{ }^{\circ} \mathrm{C}$ to obtain the final products. The mass ratio of $\mathrm{BiOI}$ to $\mathrm{La}(\mathrm{OH})_{3}$ was controlled at $25 \%$, $50 \%, 100 \%, 150 \%$ and $200 \%$, respectively. Accordingly, the products were labeled as $\mathrm{Bi} / \mathrm{La}-25 \%, \mathrm{Bi} / \mathrm{La}-50 \%$, Bi/La-100\%, $\mathrm{Bi} / \mathrm{La}-150 \%$ and $\mathrm{Bi} / \mathrm{La}-200 \%$, respectively.

\subsection{Characterization}

The crystal phases of the sample were analyzed by X-ray diffraction (XRD) with $\mathrm{Cu}-K_{\alpha}$ radiation (model D/max RA, Rigaku Co., Japan). To characterize the morphology and structure of the obtained products, transmission electron microscopy (TEM, JEM-2010, Japan) was used to collect the TEM images. Scanning electron microscopy (SEM, JEOL model JSM-6490, Japan) with X-ray energy dispersive (EDX) mapping equipment was used to characterize the morphology and composition of the samples. The Brunauer-Emmett-Teller (BET) specific surface area and pore structure of the samples were analyzed by nitrogen adsorption-desorption using nitrogen adsorption apparatus (ASAP 2020, USA) with all samples degassed at $90{ }^{\circ} \mathrm{C}$ for $12 \mathrm{~h}$ prior to the measurements. X-ray photoelectron spectroscopy with $\mathrm{Al}-K_{\alpha} \mathrm{X}$-ray $(h v=1486.6 \mathrm{eV})$ radiation operated at $150 \mathrm{~W}$ (XPS, Thermo ESCALAB 250, USA) was used to inves- 
tigate the surface properties. The UV-vis diffuse reflection spectra were obtained for the dry-pressed disk samples using a scanning UV-vis spectrophotometer (UV-vis DRS, UV-2450, China) equipped with an integrating sphere assembly, using $100 \% \mathrm{BaSO}_{4}$ as a reflectance sample. The electron spin resonance (ESR) signals of hydroxyl radicals spin-trapped by the spin-trap reagent, 5,5-dimethyl-1-pyrroline- $N$-oxide (DMPO) in water, were examined on a Bruker model ESR JES-FA200 spectrometer equipped with a Quanta-Ray Nd:YAG laser system as the irradiation source.

\subsection{Evaluation of the visible light photocatalytic activity}

The photocatalytic activity of the samples was investigated by the removal of NO at ppb levels in a continuous flow reactor. The volume of the rectangular reactor, made of stainless steel and covered with Saint-Glass, was $4.5 \mathrm{~L}(30 \mathrm{~cm} \times 15 \mathrm{~cm} \times 10$ $\mathrm{cm})$. A commercial tungsten halogen lamp $(150 \mathrm{~W})$ was vertically placed $20 \mathrm{~cm}$ above the reactor. A UV cut-off filter $(420$ $\mathrm{nm}$ ) was applied to remove UV light for the test of the photocatalytic activity in the visible light region (420-700 nm), and the average light intensity was $0.16 \mathrm{~W} / \mathrm{cm}^{2}$. For each photocatalytic activity test, two sample dishes (with a diameter of $12.0 \mathrm{~cm})$ containing the photocatalyst powder $(0.1 \mathrm{~g})$ were placed in the center of the reactor. The photocatalyst samples were prepared by coating an aqueous suspension of the samples onto the glass dishes. The coated dish was treated at $70{ }^{\circ} \mathrm{C}$ to evaporate the water and then cooled to room temperature before the photocatalytic activity test. The NO gas was acquired from a compressed gas cylinder at a concentration of $100 \mathrm{ppm}$ of NO ( $\mathrm{N}_{2}$ balance). The initial concentration of NO was diluted to $520 \mathrm{ppb}$ by an air stream of purified air. The flow rate of the air stream and NO were controlled at $2.4 \mathrm{~L} / \mathrm{min}$ and 15 $\mathrm{mL} / \mathrm{min}$, respectively. Then, the two gas streams were premixed by a three-way valve. After the adsorption-desorption equilibrium was achieved, the lamp was turned on. The concentration of NO was continuously measured by a chemiluminescence $\mathrm{NO}_{x}$ analyzer (Thermo Scientific, 42i-TL), which monitors $\mathrm{NO}, \mathrm{NO}_{2}$, and $\mathrm{NO}_{x}\left(\mathrm{NO}_{x}\right.$ represents $\left.\mathrm{NO}+\mathrm{NO}_{2}\right)$ with a sampling rate of $1.0 \mathrm{~L} / \mathrm{min}$. The removal ratio $(\eta)$ of NO was calculated as $\eta(\%)=\left(1-C / C_{0}\right) \times 100 \%$, where $C$ and $C_{0}$ are the concentrations of NO in the outlet stream and the feeding stream, respectively.

\section{Results and discussion}

\subsection{Phase structure}

The phase and crystal structures of the as-prepared samples were examined by XRD as shown in Fig. 1. The XRD peaks of the $\mathrm{La}(\mathrm{OH})_{3}$ sample agree well with the standard card of $\mathrm{La}(\mathrm{OH})_{3}$ (JCPDS-ICDD Card No. 36-1481) and no other impurities are detected, indicating a pure phase. The strongest peak at $2 \theta=27.9^{\circ}$ is representative for (101) facet reflections. The as-prepared BiOI, with dominant (012) and (110) peaks, can be indexed to tetragonal BiOI (JCPDS-ICDD Card No. 73-2062). Other diffraction peaks are missing owing to the low crystallin-

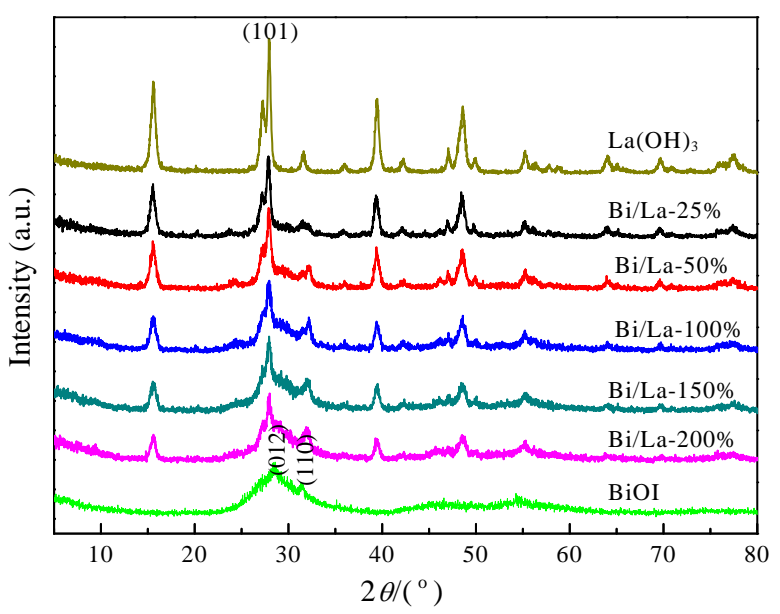

Fig. 1. XRD patterns of the as-prepared $\mathrm{La}(\mathrm{OH})_{3}, \mathrm{BiOI}$ and $\mathrm{BiOI} \mathrm{La}(\mathrm{OH})$ heterostructures.

ity of the as-prepared BiOI prepared at low temperature. Based on further observation, the peak intensity of BiOI@La(OH) composites is decreased with an increasing BiOI content, indicating the interaction and intimate contact between BiOI and $\mathrm{La}(\mathrm{OH})_{3}[23,24]$. The diffraction peaks of BiOI cannot be obviously observed even for the $\mathrm{Bi} / \mathrm{La}-200 \%$ sample, which can be ascribed to the observation that the dominant diffraction peaks of $\mathrm{BiOI}$ and $\mathrm{La}(\mathrm{OH})_{3}$ are overlapped. The formation of $\mathrm{BiOI}$ in the composites was determined with SEM and TEM.

\subsection{Morphological structure}

Fig. 2(a) and (b) show the SEM images of the pristine $\mathrm{La}(\mathrm{OH})_{3}$, which consists of dispersed $1 \mathrm{D}$ nanorods. The average diameter of the $\mathrm{La}(\mathrm{OH})_{3}$ nanorods was 30-50 nm. The SEM images of the BiOI@La(OH) heterostructures (Bi/La-150\%) are depicted in Fig. 2(c) and (d). The morphology of this sample was largely maintained, indicating that the BiOI coupling does not change the structure of the $\mathrm{La}(\mathrm{OH})_{3}$ nanorods. Further observation implied that some particles were attached on the surface of the $\mathrm{La}(\mathrm{OH})_{3}$ nanorods. The elemental mapping results (Fig. 2(a) and (b)) reveal that La, Bi, I and $\mathrm{O}$ are uniformly distributed, which also indicates that BiOI particles were evenly coupled with the $\mathrm{La}(\mathrm{OH})_{3}$ nanorods.

The microstructure of $\mathrm{La}(\mathrm{OH})_{3}$ and $\mathrm{Bi} / \mathrm{La}-150 \%$ composites was further investigated by TEM and HRTEM. Fig. 3(a) shows the typical TEM image of $\mathrm{La}(\mathrm{OH})_{3}$ with a $1 \mathrm{D}$ nanorod-like structure. The diameter of the nanorods was $30-50 \mathrm{~nm}$ and the length was 40-150 nm. Fig. 3(b) shows the typical HRTEM image of a single $\mathrm{La}(\mathrm{OH})_{3}$ nanorod. The observed spacing distance between the lattice planes was measured to be $0.565 \mathrm{~nm}$, corresponding to the (100) crystallographic planes of $\mathrm{La}(\mathrm{OH})_{3}$. According to our previous report, the $\mathrm{La}(\mathrm{OH})_{3}$ nanorod is polycrystalline [10]. Fig. 3(c) and (e) show the TEM images of the $\mathrm{Bi} / \mathrm{La}-150 \%$ composite, in which some nanoparticles were deposited on the surface of the $\mathrm{La}(\mathrm{OH})_{3}$ nanorod substrate, indicating that the composites have two distinctive morphologies of nanoparticles and nanorods. The HRTEM image of the selected area is given in Fig. 3(d). As can be seen, two sets of 


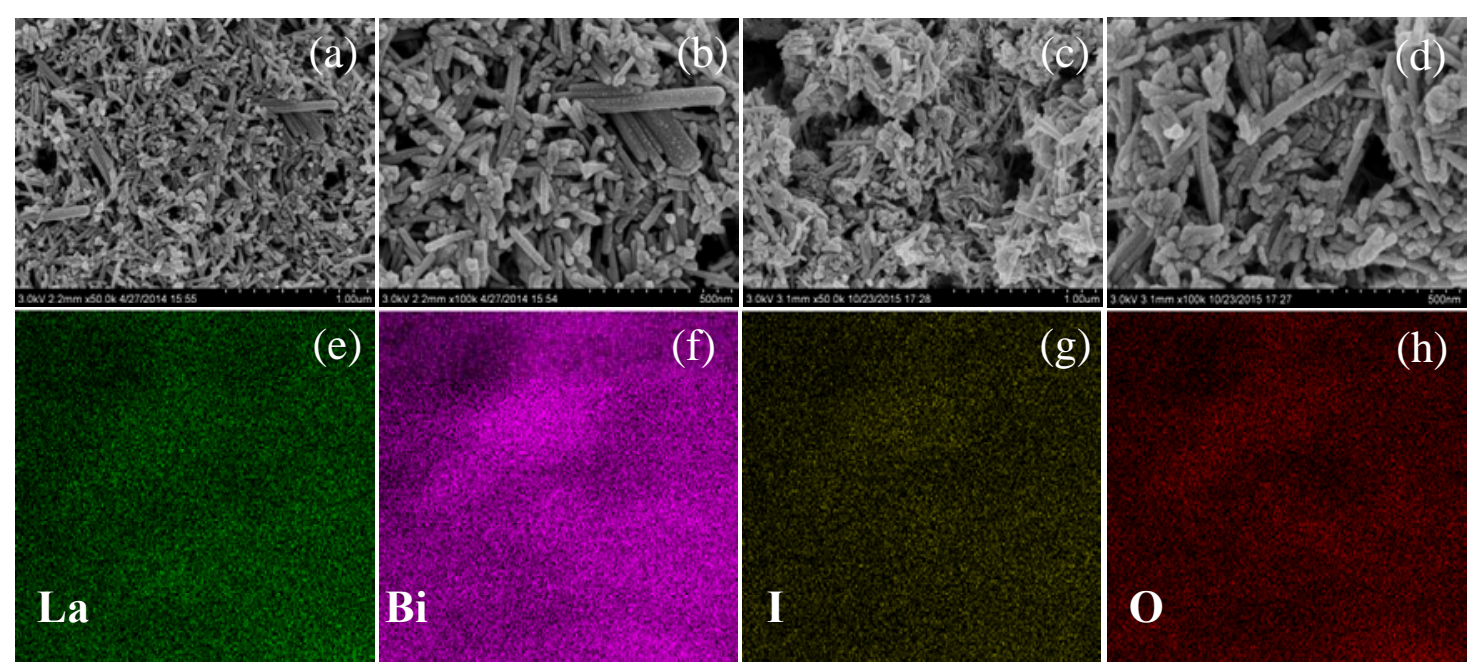

Fig. 2. SEM images of $\mathrm{La}(\mathrm{OH})_{3}(\mathrm{a}, \mathrm{b})$ and Bi/La-150\% (c, d), and elemental mapping (e, f, g, h) of Bi/La-150\%.

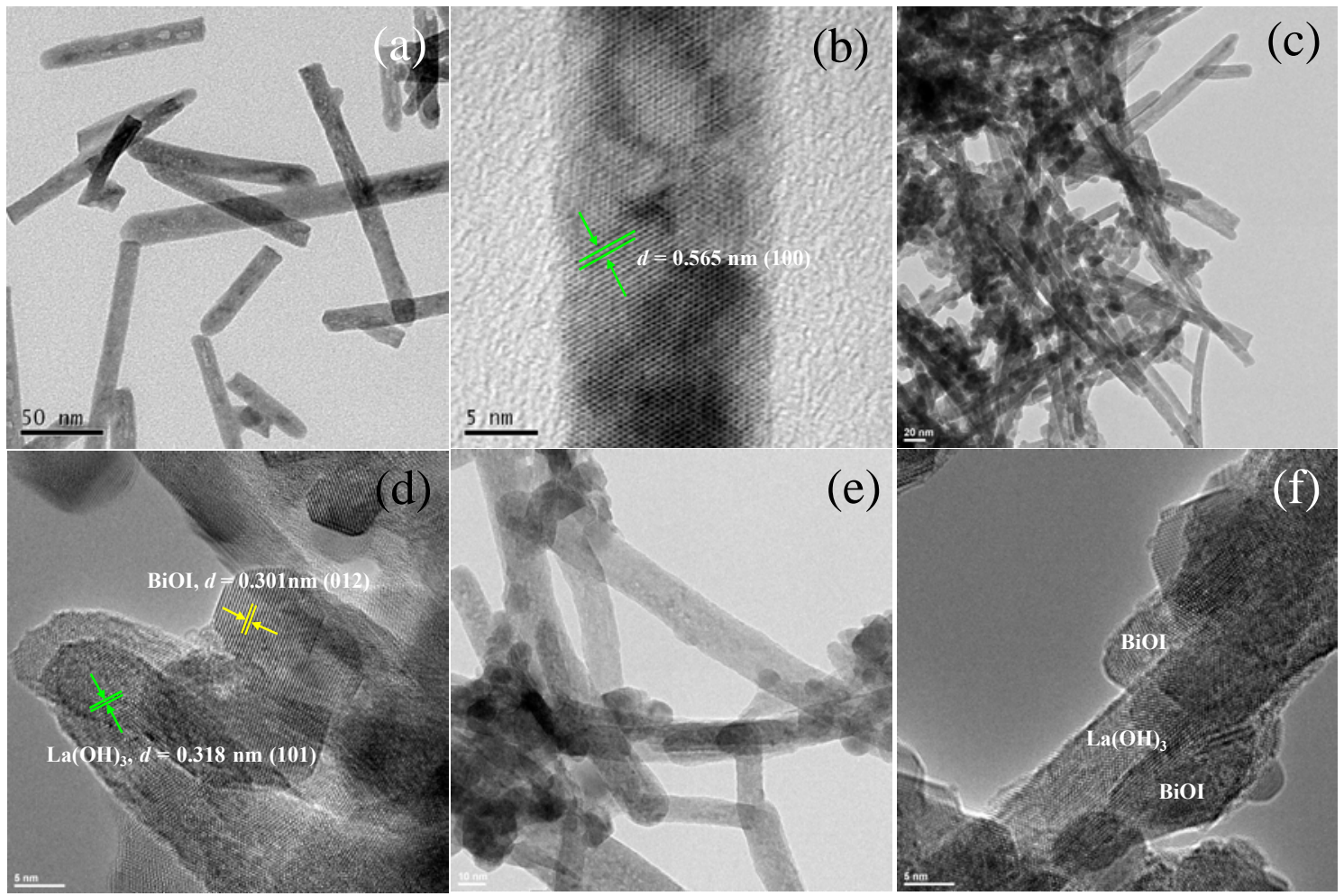

Fig. 3. TEM and HRTEM images of $\mathrm{La}(\mathrm{OH})_{3}(a, b)$ and the Bi/La-150\% heterostructure (c, d, e, f).

different fringes could be observed. The observed distinct lattice fringe of $d=0.318 \mathrm{~nm}$ on the nanorod matches well with the crystallographic plane (101) of $\mathrm{La}(\mathrm{OH})_{3}$. From the HRTEM image in Fig. 3, the pure $\mathrm{La}(\mathrm{OH})_{3}$ nanorod and $\mathrm{La}(\mathrm{OH})_{3}$ nanorod in Bi/La-150\% have different exposed crystallographic planes, which indicates that the deposition of BiOI could affect the exposed facets of the $\mathrm{La}(\mathrm{OH})_{3}$ nanorod. Note that there were some square nanoparticles observed on the surface of the $\mathrm{La}(\mathrm{OH})_{3}$ nanorod. The lattice fringe of $0.301 \mathrm{~nm}$ corresponds to the (012) crystal plane of BiOI. The results further confirm the existence of BiOI particles on the surface of the $\mathrm{La}(\mathrm{OH})_{3}$ nanorods. The HRTEM images in Fig. 3(d) and (f) demonstrate the relatively intimate interfacial contact between the BiOI parti- cles and $\mathrm{La}(\mathrm{OH})_{3}$ nanorods, which is beneficial for charge separation and transfer.

\subsection{BET surface area and pore structure}

The $\mathrm{N}_{2}$ adsorption-desorption measurement was used to study the BET surface areas ( $А \mathrm{BET}$ ) and the corresponding pore size distribution curves of pure $\mathrm{La}(\mathrm{OH})_{3}$ and BiOI@La(OH) heterostructures. Fig. 4(a) shows that all the samples exhibit typical type-IV adsorption-desorption isotherms with $\mathrm{H}_{3}$ hysteresis, which is indicative of a mesoporous structure [25,26]. The $\mathrm{H}_{3}$ hysteresis loops show high adsorption at the high relative pressure $\left(P / P_{0}\right)$ position (approaching 1.0), implying the 

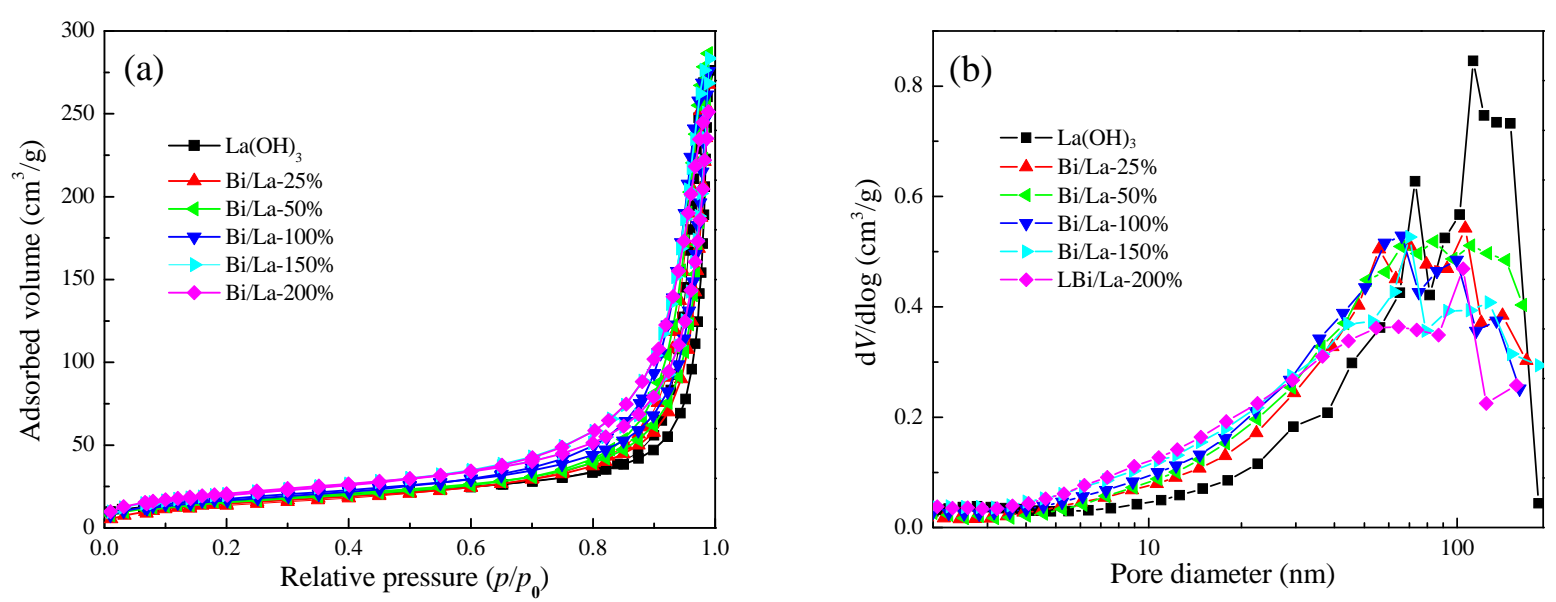

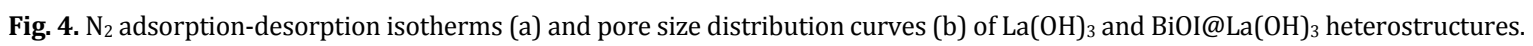

formation of large mesopores and macropores. The corresponding pore size distribution (PSD) curves of the samples are shown in Fig. 4(b), the composite samples contain macropores and large mesopores over a broad range with the peak pore sizes centered at around $20-30$ and $90-110 \mathrm{~nm}$. These results demonstrate the formation of hierarchical meso/macro porous structures in these samples. The specific surface areas and pore parameters of $\mathrm{La}(\mathrm{OH})_{3}$ and $\mathrm{BiOI} \mathrm{La}(\mathrm{OH})_{3}$ composites are summarized in Table 1. It is observed that $\mathrm{La}(\mathrm{OH})_{3}$ has a surface area of $55.0 \mathrm{~m}^{2} / \mathrm{g}$, and the specific surface area increased with an increase of the BiOI ratio in the BiOI@La(OH) 3 heterostructures. The surface areas of $\mathrm{Bi} / \mathrm{La}-150 \%$ and $\mathrm{Bi} / \mathrm{La}-200 \%$ are much higher than that of $\mathrm{La}(\mathrm{OH})_{3}$.

\subsection{Chemical composition by XPS}

The XPS measurements provide further information for the chemical composition and surface chemical states of the Bi$\mathrm{OI} @ \mathrm{La}(\mathrm{OH})_{3}$ heterostructures. The binding energies in the XPS spectra presented are calibrated by using that of $\mathrm{C} 1 \mathrm{~s}$ (284.8 $\mathrm{eV}$ ). As displayed in Fig. 5(a), the Bi $4 f$ spectra for BiOI consist of two peaks with binding energies around 159.8 and $165.2 \mathrm{eV}$, which correspond to the signals from the doublets of Bi $4 f_{7 / 2}$ and $\mathrm{Bi} 4 f_{5 / 2}$ in the trivalent oxidation state [27-28]. These two peaks of $\mathrm{Bi} 4 f$ in $\mathrm{Bi} / \mathrm{La}-150 \%$ have a shift of $0.6 \mathrm{eV}$ to the low energy region compared with those for pure BiOI. The XPS spectra of I $3 d$ is shown in Fig. 5(b). The binding energies at $619.1 \mathrm{eV}$ (I $3 d_{5 / 2}$ ) and $630.6 \mathrm{eV}$ (I $3 d_{3 / 2}$ ) could be ascribed to the $\mathrm{I}^{-}$ions in BiOI $[21,24,29]$. These binding energies of

Table 1

$A_{\mathrm{BET}}$, pore parameters and NO removal ratio of the samples.

\begin{tabular}{lcccr}
\hline Sample & $\begin{array}{c}A_{\text {BET }} \\
\left(\mathrm{m}^{2} / \mathrm{g}\right)\end{array}$ & $\begin{array}{c}\text { Pore volume } \\
\left(\mathrm{cm}^{3} / \mathrm{g}\right)\end{array}$ & $\begin{array}{c}\text { Peak pore size } \\
(\mathrm{nm})\end{array}$ & $\begin{array}{r}\eta(\mathrm{NO}) \\
(\%)\end{array}$ \\
\hline $\mathrm{La}(\mathrm{OH})_{3}$ & 55.0 & 0.41 & 30.07 & 3.9 \\
$\mathrm{Bi} / \mathrm{La}-25 \%$ & 55.1 & 0.41 & 30.07 & 21.1 \\
$\mathrm{Bi} / \mathrm{La}-50 \%$ & 60.4 & 0.44 & 29.34 & 28.9 \\
$\mathrm{Bi} / \mathrm{La}-100 \%$ & 64.8 & 0.43 & 26.31 & 35.9 \\
$\mathrm{Bi} / \mathrm{La}-150 \%$ & 74.9 & 0.44 & 23.41 & 50.5 \\
$\mathrm{Bi} / \mathrm{La}-200 \%$ & 75.2 & 0.44 & 23.41 & 48.6 \\
\hline
\end{tabular}

Bi/La-150\% exhibit a negative shift of 0.4 eV. Fig. 5(c) shows the typical La $3 d_{3 / 2}$ XPS spectra. A double-peak structure with a peak energy of $838.0 \mathrm{eV}$ and satellite energy of $855.4 \mathrm{eV}$ could be observed. The high binding energy of the satellite can be ascribed to the shake-up process associated with the $02 p$-La $4 f$ charge transfer [30]. The $01 s$ peaks for the BiOI@La(OH) heterostructure in Fig. 5(d) can be fitted to two peaks. The peak at $529.6 \mathrm{eV}$ corresponds to the $\mathrm{Bi}-\mathrm{O}$ bonds, and the peak at $531.04 \mathrm{eV}$ can be attributed to the La-O bond. Compared with pure BiOI, the $01 s$ peak exhibits a $0.3 \mathrm{eV}$ shift to a lower binding energy [22,31]. The peaks of $\mathrm{Bi} 4 f$, I $3 d$ and $02 p$ undergo chemical shifts in the heterostructure, which can be attributed to the $\mathrm{Bi}, \mathrm{I}$ and $\mathrm{O}$ bonding with $\mathrm{La}$ in $\mathrm{La}(\mathrm{OH})_{3}$. These results suggest an interaction between $\mathrm{La}(\mathrm{OH})_{3}$ and BiOI, confirming the existence of chemical bonds between $\mathrm{La}(\mathrm{OH})_{3}$ and $\mathrm{BiOI}$ in the heterostructures, which is consistent with the XRD result.

\subsection{Optical absorption property}

The pure $\mathrm{La}(\mathrm{OH})_{3}$ and BiOI@La(OH)$)_{3}$ heterostructures with an increasing mass ratio of BiOI show a gradient color deepening from white to yellow. From Fig. 6(a), it can be found that the pure $\mathrm{La}(\mathrm{OH})_{3}$ nanorods display an absorption edge in the UV region, and no absorption in the visible light region. Note that the peak at approximately $270 \mathrm{~nm}$ can be ascribed to the oxygen defects in $\mathrm{La}(\mathrm{OH})_{3}$ nanorods [10]. Pure BiOI has a strong absorption in the visible light range with an absorption edge around $560 \mathrm{~nm}$. All the BiOI@La(OH)3 heterostructures exhibit a clear optical response in the visible region owing to the coupling with BiOI. An increase of the BiOI content exerts an obvious influence on the visible light absorption of BiOI@La(OH)3 heterostructures. This interesting observation can arise from the special properties of BiOI with a small band gap, large absorption coefficient and strong absorption in the visible light range. It can be concluded that the introduction of BiOI into $\mathrm{La}(\mathrm{OH})_{3}$ nanorods benefits the optical absorption property and efficiency for visible light. The absorption enhancement in the visible light region is beneficial for an enhancement of the photocatalytic activity. 

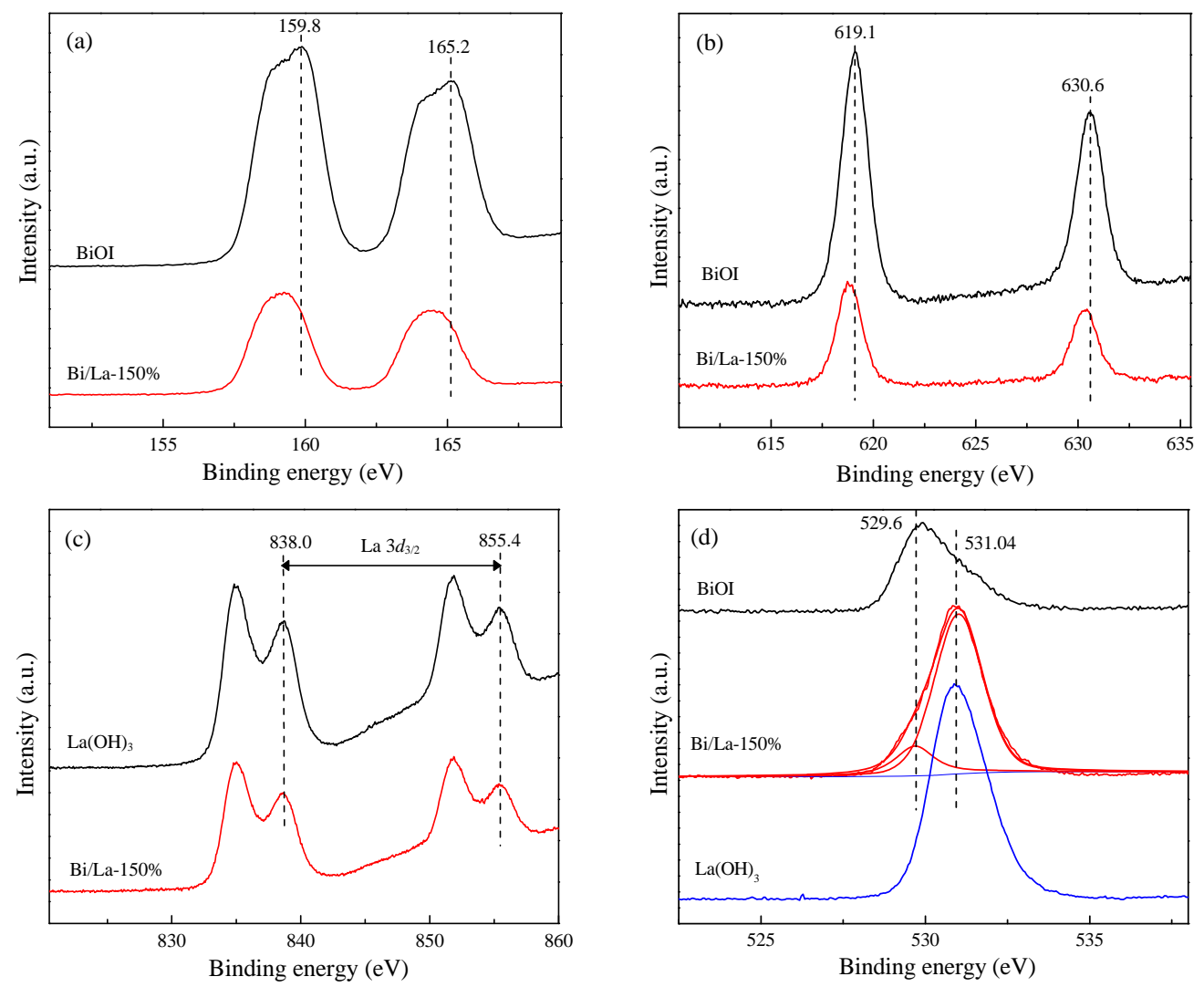

Fig. 5. XPS spectra of BiOI and the Bi/La-150\% heterostructure. (a) Bi 4f; (b) I 3d; (c) La 3d; (d) $01 s$.

The band gap energy of a semiconductor could be calculated by the following formula: $\alpha h v=A\left(h v-E_{\mathrm{g}}\right)^{n / 2}$, where $\alpha, v, E_{\mathrm{g}}$ and $\mathrm{A}$ are the absorption coefficient, light frequency, band gap and a constant, respectively. Among them, $n$ depends on the characteristics of the transition in a semiconductor, including a direct transition $(n=1)$ or indirect transition $(n=4)$. For BiOI and $\mathrm{La}(\mathrm{OH})_{3}$, the values of $n$ are both 4 as for the indirect transition. Therefore, the band gap energy $\left(E_{\mathrm{g}}\right)$ of the samples can be estimated from a plot of $(\alpha h v)^{1 / 2}$ versus photon energy $(h v)$. The intercept of the tangent to the plot gives a good approximation of the band gap energy of the sample (Fig. 6(b)) [32,33]. The band gap of BiOI is evaluated to be approximately $2.0 \mathrm{eV}$, while of $\mathrm{La}(\mathrm{OH})_{3}$ is found to be approximately $3.41 \mathrm{eV}$. The band edge positions adopted can be determined theoretically from the absolute electronegativity, which is a simple method with reasonable results for many photocatalysts $[34,35]$. The VB edge potential of a semiconductor at the point of zero charge can be calculated by the following empirical equation: $E_{\mathrm{VB}}=\mathrm{X}-E_{\mathrm{c}}+$ $0.5 E_{\mathrm{g}}$, where $X$ is the absolute electronegativity of the semiconductor, which is the geometric mean of the electronegativity of the constituent atoms. Herein, the electronegativity of an atom is the arithmetic mean of the atomic electron affinity and
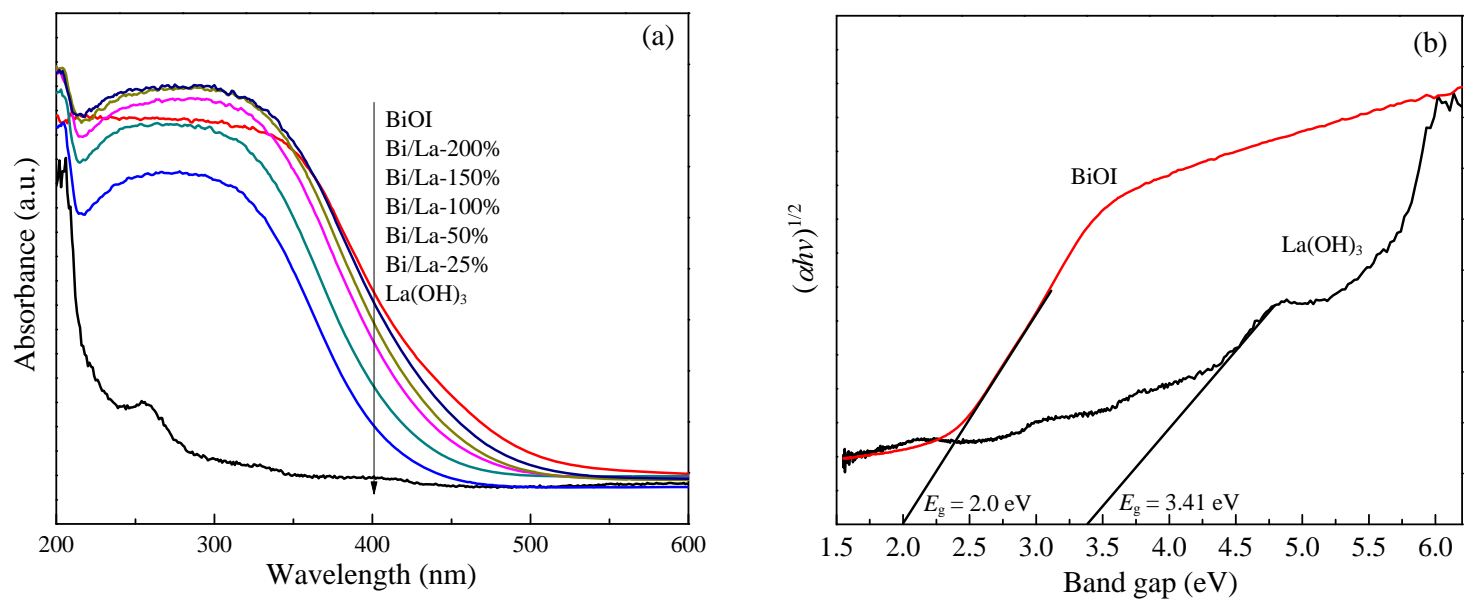

Fig. 6. UV-vis DRS spectra (a) and plots of $(\alpha h v)^{1 / 2}$ versus photon energy (b) of the as-prepared samples. 
Table 2

Absolute electronegativity, band gap energy, calculated CB edge, and calculated $\mathrm{VB}$ position for $\mathrm{BiOI}$ and $\mathrm{La}(\mathrm{OH})_{3}$ at the point of zero charge.

\begin{tabular}{lcccc}
\hline Sample & $\begin{array}{c}\text { Absolute } \\
\text { electro-negativity } \\
(X)(\mathrm{eV})\end{array}$ & $\begin{array}{c}\text { Band gap } \\
\text { energy } \\
(\mathrm{eV})\end{array}$ & $\begin{array}{c}\text { Calculated } \\
\mathrm{CB} \text { position } \\
(\mathrm{eV})\end{array}$ & $\begin{array}{c}\text { Calculated } \\
\text { VB position } \\
(\mathrm{eV})\end{array}$ \\
\hline $\mathrm{BiOI}$ & 5.99 & 2.00 & 0.49 & 2.49 \\
$\mathrm{La}(\mathrm{OH})_{3}$ & 5.67 & 3.41 & -0.41 & 2.88 \\
\hline
\end{tabular}

the first ionization energy, $E_{\mathrm{c}}$ is the energy of free electrons on the hydrogen scale (approximately $4.5 \mathrm{eV}$ ), and $E_{\mathrm{g}}$ is the band gap energy. Moreover, the conduction band (CB) edge potential $\left(E_{\mathrm{CB}}\right)$ can be determined by $E_{\mathrm{CB}}=E_{\mathrm{VB}}-E_{\mathrm{g}}$. The $X$ values for $\mathrm{La}(\mathrm{OH})_{3}$ and $\mathrm{BiOI}$ are 5.67 and $5.99 \mathrm{eV}[36,37]$. Hence, the $E_{\mathrm{VB}}$ of $\mathrm{La}(\mathrm{OH})_{3}$ and $\mathrm{BiOI}$ are calculated to be 2.88 and $2.49 \mathrm{eV}$, respectively. At last, the $E_{\mathrm{CB}}$ of $\mathrm{La}(\mathrm{OH})_{3}$ and $\mathrm{BiOI}$ were estimated to be -0.41 and $0.49 \mathrm{eV}$. The calculated potentials of the $\mathrm{CB}$ and $\mathrm{VB}$ of $\mathrm{La}(\mathrm{OH})_{3}$ and BiOI are listed in Table 2 .

\subsection{Photocatalytic activity and stability}

The as-prepared samples were used for the photocatalytic removal of ppb-level NO in the gas phase to demonstrate their potential capability for use in air purification. Fig. 7(a) shows the variation of the NO concentration $\left(C / C_{0}\right)$ with irradiation time under visible light irradiation. NO could not be photolyzed under light irradiation $(\lambda>420 \mathrm{~nm})$. In the presence of photocatalysts, NO reacts with the photogenerated reactive radicals to produce the final product. Fig. 7(a) shows the variation in NO concentration with irradiation time for the seven photocatalysts under visible light irradiation. $\mathrm{La}(\mathrm{OH})_{3}$ exhibits a negligible photocatalytic activity owing to its large band gap. Meanwhile, the BiOI showed negligible photocatalytic activity owing to the rapid recombination of photoinduced electrons and holes. When a small amount of BiOI was introduced on the surface of $\mathrm{La}(\mathrm{OH})_{3}$ nanorods, the photocatalytic NO removal ratio could be significantly enhanced. The Bi/La-150\% exhibits the highest photocatalytic activity with a NO removal ratio of $50.5 \%$, which is superior to $\mathrm{N}$-doped $\mathrm{TiO}_{2}$ and g- $\mathrm{C}_{3} \mathrm{~N}_{4}$. Mean- while, the other BiOI@La(OH) 3 heterostructures showed a slightly lower activity, which was still higher than the pure $\mathrm{La}(\mathrm{OH})_{3}$ or BiOI sample. The enhanced photocatalytic activity of the BiOI@La $(\mathrm{OH})_{3}$ samples could be attributed to the heterostructure with intimate contact resulting in the promotion of charge separation. However, excessive BiOI in the heterostructures might reduce the production of the reactive species owing to the increased charge recombination by BiOI. Similar phenomena have been observed for $\mathrm{BiVO}_{4} / \mathrm{Bi}_{2} \mathrm{~S}_{3}$ and $\mathrm{Bi}_{2} \mathrm{MoO}_{6} / \mathrm{BiOCl}$ photocatalysts [38,39]. Note that the decreased activity of $\mathrm{Bi} / \mathrm{La}-100 \%$ after $5 \mathrm{~min}$ can be ascribed to the accumulation of the reaction products on the catalyst surface.

It is important for the photocatalyst to maintain its stability under recycled runs. Fig. 7(b) demonstrates the cycling runs for the $\mathrm{Bi} / \mathrm{La}-150 \%$ sample. After consecutive repeated irradiation, the high NO removal ratio can be maintained, which indicates the high photochemical stability of the BiOI@La(OH) 3 heterostructure. The used catalyst can be regenerated by washing it with water to remove the accumulated species.

\subsection{Photocatalytic mechanism of the BiOI@La $(\mathrm{OH})_{3}$ heterostructure}

It is important to determine the main oxidative species in the photocatalytic process to elucidate the photocatalysis mechanism [41].ESR is a powerful technique for the detection of photogenerated radicals in the photocatalysis process $[41,42]$. DMPO is generally used for trapping radicals owing to the generation of some stable radicals, such as the DMPO-hydroxyl radical $(\cdot \mathrm{OH})$ and DMPO-superoxide radical $\left(\cdot \mathrm{O}_{2}{ }^{-}\right)$. The ESR technique is thus employed to monitor the reactive species generated during the light irradiation of the BiOI@La(OH)3 heterostructure with DMPO in methanol and water, and the results are shown in Fig. 8. The signals of the superoxide $\left(\cdot \mathrm{O}_{2}-\right)$ cannot be obviously observed. However, the signals of the hydroxyl radical $(\cdot \mathrm{OH})$ could be observed when the BiOI@La $(\mathrm{OH})_{3}$ suspension is irradiated for $5 \mathrm{~min}$ by a pulsed laser system. Besides, the intensity of the $\cdot \mathrm{OH}$ signal from the Bi/La-150\% sample increased considerably after ir-
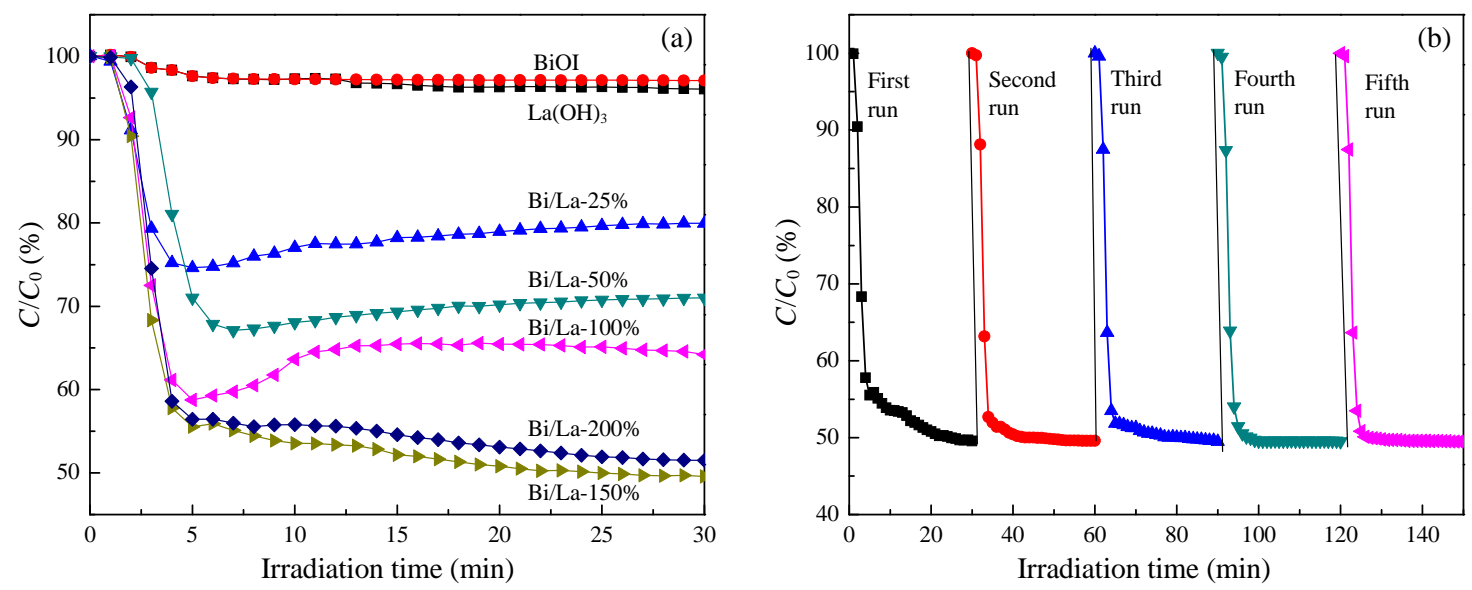

Fig. 7. Photocatalytic oxidation of NO over the as-prepared samples (a), and cycling runs of the Bi/La-150\% heterostructure in air under visible light irradiation (b). 

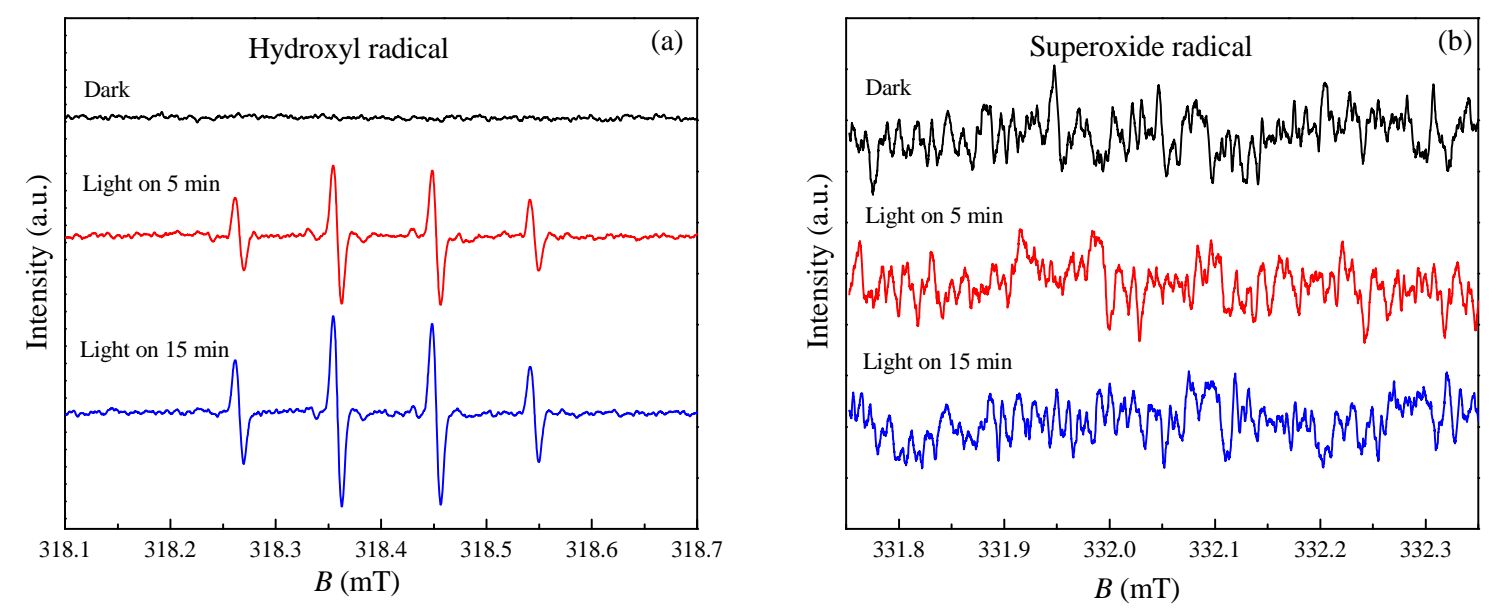

Fig. 8. DMPO spin-trapping ESR spectra of the $\mathrm{Bi} / \mathrm{La}-150 \%$ heterostructure in a methanol dispersion for ${ }^{\circ} \mathrm{OH}(\mathrm{a})$ and in an aqueous dispersion for ${ }^{\circ} \mathrm{O}^{2-}$ (b).

radiation for $15 \mathrm{~min}$. Therefore, the hydroxyl radical $(\cdot \mathrm{OH})$ is the main oxidative species for the BiOI@La(OH) 3 system. The NO could react with the photogenerated $\cdot \mathrm{OH}$ radicals generated from the photocatalytic reaction to produce the final products of $\mathrm{NO}_{3}{ }^{-}$, which involves the three reactions presented in Eqs. (1)-(3) $[43,44]$.

$$
\begin{aligned}
\mathrm{NO}+2 \cdot \mathrm{OH} & \rightarrow \mathrm{NO}_{2}+\mathrm{H}_{2} \mathrm{O} \\
\mathrm{NO}_{2}+\cdot \mathrm{OH} & \rightarrow \mathrm{NO}_{3}{ }^{-}+\mathrm{H}^{+} \\
\mathrm{NO}+\cdot \mathrm{O}_{2}- & \rightarrow \mathrm{NO}_{3}^{-}
\end{aligned}
$$

Based on the above results, the enhanced photocatalytic activity of the BiOI@La(OH) 3 heterostructures can be attributed to the following reasons. First, the photocatalytic reaction is often related to the specific surface areas. High specific surface areas could facilitate the diffusion of reactants and products on the catalyst surface. In our case, the BiOI@La(OH)3 heterostructures possess higher specific surface areas than the $\mathrm{La}(\mathrm{OH})_{3}$ nanorods, which favors the photocatalytic reaction. Second, the photocatalysis efficiency is related the band gap energy $\left(E_{\mathrm{g}}\right)$ of the photocatalyst to some extent. A small $E_{\mathrm{g}}$ value means that the catalyst can use visible light more efficiently, but also means the redox ability of the photogenerated charge carriers becomes weak. These competitive effects lead to the reasonable result that the photocatalytic activity of $\mathrm{Bi}$ $\mathrm{OI} @ \mathrm{La}(\mathrm{OH})_{3}$ heterostructures does not increase monotonically with the BiOI content, but reaches a maximum with an appropriate amount of BiOI. Third, the enhanced visible light photocatalytic activity of BiOI@La(OH) 3 heterostructures can be mostly ascribed to the efficient separation of photogenerated charge carriers by the heterojunction.

The flowchart of the photogenerated electrons and holes at the heterojunction interface depends on band edge positions of semiconductors. The band alignment of the BiOI@La(OH) heterostructure is schematically given in Fig. 9. The BiOI with a narrow band gap energy $(2.0 \mathrm{eV})$ could easily be excited by visible light $(\lambda>420 \mathrm{~nm}$, energy $<2.95 \mathrm{eV})$ to induce the generation of photoelectrons and holes. However, these photoelectrons and holes might also recombine rapidly because of the narrow energy gap. This is why BiOI shows a poor photocata- lytic activity. $\mathrm{La}(\mathrm{OH})_{3}$ could not be excited by visible light irradiation with energy less than $2.95 \mathrm{eV}(\lambda>420 \mathrm{~nm})$ owing to its wide energy gap of $3.41 \mathrm{eV}$. When a BiOI@La(OH)3 heterostructure is formed, BiOI could act as a sensitizer to absorb the visible light. Under visible light illumination with energy of 2.95 $\mathrm{eV}(\lambda>420 \mathrm{~nm})$, electrons in the valence band of BiOI could be excited up to a higher potential edge $(-0.56 \mathrm{eV})[21,45]$. The reformed $\mathrm{CB}$ edge potential of BiOI is more active than that of $\mathrm{La}(\mathrm{OH})_{3}(-0.41 \mathrm{eV})$. The photogenerated electrons in the $\mathrm{CB}$ of $\mathrm{BiOI}$ transfer to the $\mathrm{CB}$ of $\mathrm{La}(\mathrm{OH})_{3}$ through the intimate interface, while holes remain in the valence band (VB). The potential of the electrons in the conduction band of $\mathrm{La}(\mathrm{OH})_{3}(-0.51 \mathrm{eV})$ is more negative than the potential of $\mathrm{O}_{2} /{ }^{\cdot} \mathrm{O}_{2}{ }^{-}(-0.33 \mathrm{eV}$ vs NHE), so ${ }^{\circ} \mathrm{O}_{2}$ - should be produced. However, the generated ${ }^{\circ} \mathrm{O}_{2}{ }^{-}$can be rapidly transformed into $\cdot \mathrm{OH}$. Meanwhile, the potential of the holes at the $\mathrm{VB}$ of $\mathrm{BiOI}(2.49 \mathrm{eV})$ is more positive than the redox potential of $\mathrm{OH}^{-} / \cdot \mathrm{OH}(1.99 \mathrm{eV})$, and therefore, the holes could directly oxidize $\mathrm{OH}^{-}$to $\bullet \mathrm{OH}$. Therefore, the photoinduced electron-hole pairs generated from BiOI could be effectively sepa-

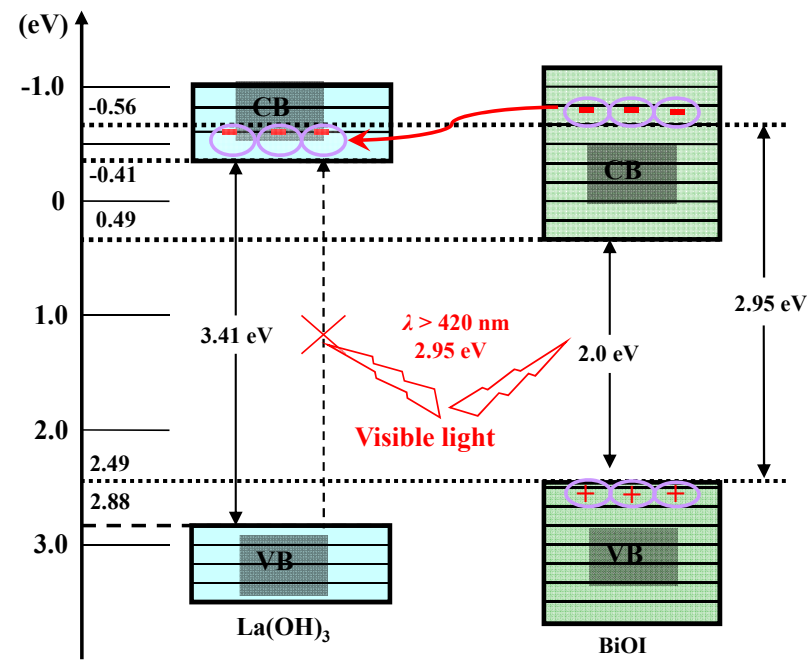

Fig. 9. Photocatalytic mechanism of the as-prepared BiOI@La(OH) heterostructure. 
rated, and thus the BiOI@La(OH) 3 heterostructures exhibit a highly enhanced photocatalytic performance for the removal of NO under visible light irradiation.

\section{Conclusions}

We have developed a facile synthetic approach to construct heterostructured BiOI@La(OH) 3 nanorods. The presence of BiOI could extend the light response of $\mathrm{La}(\mathrm{OH})_{3}$ from the UV to the visible light region. The heterostructure with an intimate interface and well-matched band position was confirmed by various characterization techniques. This heterostructure could promote the charge separation and transfer, thus leading to an enhanced visible light photocatalytic activity. Among the as-prepared samples, Bi/La-150\% showed the highest photocatalytic activity, which suggested that the mass ratio of BiOI plays an important role in enhancing the visible light photocatalysis of the $\mathrm{La}(\mathrm{OH})_{3}$. A new photocatalysis mechanism for photocatalytic NO purification with the BiOI@La(OH) 3 heterostructure was proposed. Our work could provide new insights into the development and application of heterostructured photocatalysts.

\section{References}

[1] A. Fujishima, K. Honda, Nature, 1972, 238, 37-38.

[2] X. B. Chen, S. H. Shen, L. J. Guo, S. S. Mao, Chem. Rev., 2010, 110, 6503-6570.

[3] T. Xiong, H. J. Zhang, Y. X. Zhang, F. Dong, Chin. J. Catal., 2015, 36, 2155-2163.

[4] Z. W. Zhao, Y. J. Sun, F. Dong, Nanoscale, 2015, 7, 15-37.

[5] L. Shang, B. Tong, H. J. Yu, G. I. N. Waterhouse, C. Zhou, Y. F. Zhao, M. Tahir, L. Z. Wu, C. H. Tung, T. R. Zhang, Adv. Energy Mater, 2016, 6, 1501241.

[6] Y. F. Zhao, G. B. Chen, L. Z. Wu, C. H. Tung, T. R. Zhang, B. Zhao, S. Y. Yao, M. Z. Li, J. L. Xie, D. Ma, J. Liu, R. Gao, X. D. Wen, Q. H. Zhang, L. $\mathrm{Gu}$, Angew. Chem. Int. Ed., 2016, 55, 4215-4219.

[7] H. J. Yu, Y. F. Zhao, C. Zhou, L. Shang, Y. Peng, Y. H. Cao, L. Z. Wu, C. H. Tung, T. R. Zhang, J. Mater. Chem. A, 2014, 2, 3344-3351.

[8] X. Feng, W. Zhang, H. Deng, Z. Ni, F. Dong, Y. Zhang, J. Hazard. Mater., 2017, 322, 223-232.

[9] Y. Wang, S. Y. Liu, Y. Cai, S. J. Deng, B. Q. Han, R. Han, Q. Li, Y. D.
Wang, Ceram. Int., 2014, 40, 5091-5095.

[10] F. Dong, X. Xiao, G. G. Jiang, Y. X. Zhang, W. Cui, J. Z. Ma, Phys. Chem. Chem. Phys., 2015, 17, 16058-16066.

[11] X. Xiao, W. D. Zhang, J. Y. Yu, Y. J. Sun, Y. X. Zhang, F. Dong, Catal. Sci. Technol., 2016, 6, 5003-5010.

[12] P. Li, X. Zhao, C. J. Jia, H. G. Sun, L. M. Sun, X. F. Cheng, L. Liu, W. L. Fan, J. Mater. Chem. A, 2013, 1, 3421-3429.

[13] F. Dong, T. Xiong, S. Yan, H. Wang, Y. Sun, Y. Zhang, H. Huang, Z. $\mathrm{Wu}$, J. Catal., 2016, 344, 401-410.

[14] S. Q. Han, J. Li, K. L. Yang, J. Lin, Chin. J. Catal., 2015, 36, 2119-2126.

[15] H. Q. Li, Y. M. Cui, W. S. Hong, B. L. Xu, Chem. Eng. J., 2013, 228, 1110-1120.

[16] D. L. Jiang, L. L. Chen, J. J. Zhu, M. Chen, W. D. Shi, J. M. Xie, Dalton Trans., 2013, 42, 15726-15734.

[17] X. Zhang, Z. H. Ai, F. L. Jia, L. Z. Zhang, J. Phys. Chem. C, 2008, 112, 747-753.

[18] J. Cao, B. Y. Xu, B. D. Luo, H. L. Lin, S. F. Chen, Catal. Commun., 2011, $13,63-68$.

[19] X. F. Chang, J. Huang, C. Cheng, Q. Sui, W. Sha, G. B. Ji, S. B. Deng, G. Yu, Catal. Commun., 2010, 11, 460-464.

[20] H. F. Cheng, B. B. Huang, Y. Dai, X. Y. Qin, X. Y. Zhang, Langmuir, 2010, 26, 6618-6624.

[21] X. Zhang, L. Z. Zhang, T. F. Xie, D. J. Wang, J. Phys. Chem. C, 2009, $113,7371-7378$.

[22] J. Jiang, X. Zhang, P. B. Sun, L. Z. Zhang, J. Phys. Chem. C, 2011, 115, 20555-20564.

[23] D. F. Hou, X. L. Hu, P. Hu, W. Zhang, M. F. Zhang, Y. H. Huang, Nanoscale, 2013, 5, 9764-9772.

[24] H. R. Li, Z. Jin, H. G. Sun, L. M. Sun, Q. B. Li, X. Zhao, C. J. Jia, W. L. Fan, Mater. Res. Bull., 2014, 55, 196-204.

[25] Q. J. Xiang, B. Cheng, J. G. Yu, Appl. Catal. B, 2013, 138-139, 299-303.

[26] J. Zhang, S. W. Liu, J. G. Yu, M. Jaroniec, J. Mater. Chem., 2011, 21, 14655-14662.

[27] W. B. Luo, J. Zhu, Y. R. Li, X. P. Wang, D. Zhao, J. Xiong, Y. Zhang, Appl. Phys. Lett., 2007, 91, 082501/1-082501/3.

[28] Y. Huang, Z. H. Ai, W. Ho, M. J. Chen, S. C. Lee, J. Phys. Chem. C, 2010, $114,6342-6349$.

[29] Z. Liu, W. C. Xu, J. Z. Fang, X. X. Xu, S. X. Wu, X. M. Zhu, Z. H. Chen, Appl. Surf. Sci., 2012, 259, 441-447.

[30] H. Wong, H. Iwai, K. Kakushima, B. L. Yang, P. K. Chu, J. Electrochem. Soc., 2010, 157, G49-G52.

[31] K. L. Zhang, C. M. Liu, F. Q. Huang, C. Zheng, W. D. Wang, Appl. Catal. B, 2006, 68, 125-129.

\section{Graphical Abstract}

Chin. J. Catal., 2017, 38: 217-226 doi: 10.1016/S1872-2067(17)62753-0

\section{Heterostructured BiOI@La(OH) 3 nanorods with enhanced visible light photocatalytic NO removal}

Yanjuan Sun, Xiang Xiao, Xing'an Dong, Fan Dong*, Wei Zhang* Chongqing Technology and Business University; Chongqing Institute of Green and Intelligent Technology, Chinese Academy of Sciences

Heterostructured BiOI@La(OH) 3 nanorods with efficient visible light photocatalytic performance are synthesized by a facile chemical impregnation method.

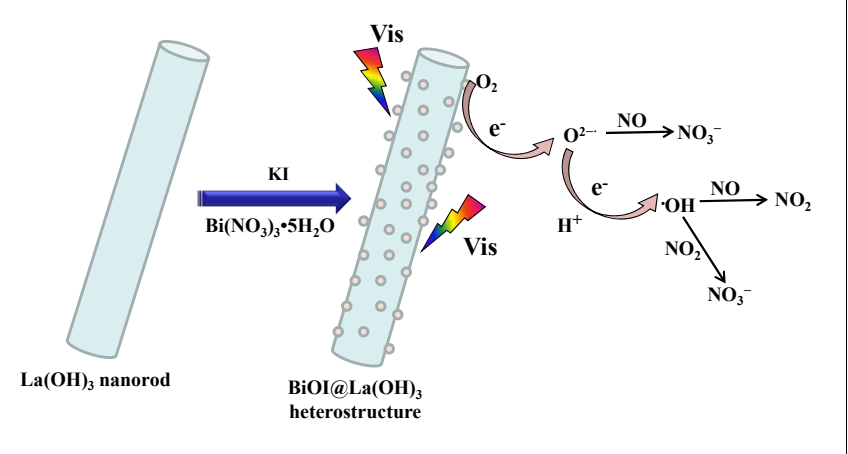


[32] H. Q. Jiang, M. Nagai, K. Kobayashi, J. Alloys Compd., 2009, 479, 821-827.

[33] Z. B. Wu, F. Don, Y. Liu, H. Q. Wang, Catal. Commun., 2009, 11, 82-86.

[34] M. C. Long, W. M. Cai, J. Cai, B. X. Zhou, X. Y. Chai, Y. H. Wu, J. Phys. Chem. B, 2006,110, 20211-20216.

[35] X. Zhang, Z. H. Ai, F. L. Jia, L. J. Zhang, Phys. Chem. C, 2008, 112,747-753.

[36] J. Cao, X. Li, H. L. Lin, B. Y. Xu, S. F. Chen, Q. M. Guan, Appl. Surf. Sci., 2013, 266, 294-299.

[37] F. Dong, T. Xiong, Y. J. Sun, Y. X. Zhang, Y. Zhou, Chem. Commun., 2015, 51, 8249-8253.

[38] X. H. Gao, H. B. Wu, L. X. Zheng, Y. J. Zhong, Y. Hu, X. W. Lou, Angew. Chem. Int. Ed., 2014, 53, 5917-5921.
[39] D. Yue, D. M. Chen, Z. H. Wang, H. Ding, R. L. Zong, Y. F. Zhu, Phys. Chem. Chem. Phys., 2014, 16, 26314-26321.

[40] S. K. Muduli, S. Wang, S. Chen, C. F. Ng, C. H. A. Huan, T. C. Sum, H. S. Soo, Beilstein J. Nanotechnol, 2014, 5, 517-523.

[41] T. G. Xu, L. W. Zhang, H. Y. Cheng, Y. F. Zhu, Appl. Catal. B, 2011, 101, 382-387.

[42] T. Xia, Y. L. Zhang, J. Murowchickc, X. B. Chen, Catal. Today, 2014, $225,2-9$.

[43] X. Ding, X. Song, P. N. Li, Z. H. Ai, L. Z. Zhang, J. Hazard. Mater., 2011, 190, 604-612.

[44] Y. Zhou, X. J. Zhang, Q. Zhang, F. Dong, F. Wang, Z. Xiong, J. Mater. Chem. A, 2014, 2, 16623-16631.

[45] Z. S. Liu, H. S. Ran, B. T. Wu, P. Z. Feng, Y. B. Zhu, Colloids Surf. A, 2014, 452, 109-114.

\title{
BiOI@La $(\mathrm{OH})_{3}$ 纳米棒异质结制备及其增强可见光催化去除NO性能
}

\author{
孙艳娟, 肖 香 ${ }^{\mathrm{a}}$, 董兴安 ${ }^{\mathrm{a}}$, 董 帆 ${ }^{\mathrm{a}, *}$, 张 炜, ${ }^{\mathrm{b}, \#}$
}

a 重庆工商大学环境与资源学院, 重庆市催化与环境新材料重点实验室, 教育部废油资源化技术与装备工程研究中心, 重庆400067 $\mathrm{b}$ 中国科学院重庆绿色智能技术研究院, 重庆 400714

摘要: 一维 $\mathrm{La}(\mathrm{OH})_{3}$ 纳米棒具有特殊的电子结构和多功能特性, 特别是作为半导体光催化剂引起了人们极大的兴趣. 但 $\mathrm{La}(\mathrm{OH})_{3}$ 禁带宽度较大, 且只能吸收紫外光, 所以光催化效率较低, 可见光利用能力较差, 限制了 $\mathrm{La}(\mathrm{OH})_{3}$ 的实际应用. 因此, 需要开发一种高效的改进方法来提高 $\mathrm{La}(\mathrm{OH})_{3}$ 的可见光催化性能. 本课题组发展了一种有效的改进 $\mathrm{La}(\mathrm{OH})_{3}$ 方法, 通过简易 的方法将 $\mathrm{BiOI}$ 纳米颗粒沉积在 $\mathrm{La}(\mathrm{OH})_{3}$ 纳米棒上, 有效增强了对可见光的吸收能力和光生载流子的分离能力. 本文采用 $\mathrm{X}$ 射线衍射(XRD)、透射电镜(TEM)、扫描电镜(SEM)、紫外-可见漫反射光谱(UV-Vis DRS)、苂光光谱(PL)、光电子能谱(XPS)、 电子自旋共振 $(\mathrm{ESR}) 、 \mathrm{~N}_{2}$ 吸附和元素分析等手段研究了 $\mathrm{BiOI} @ \mathrm{La}(\mathrm{OH})_{3}$ 纳米棒异质结的构建原理及增强可见光催化性能的 原因.

XRD和XPS结果表明, 通过简易化学沉积法原位构建了 $\mathrm{BiOI} @ \mathrm{La}(\mathrm{OH})_{3}$ 异质结, 并且在异质结中没有杂相生成. 由SEM 图像可见, 原始 $\mathrm{La}(\mathrm{OH})_{3}$ 由分散的一维纳米棒组成, 平均直径为 $30-50 \mathrm{~nm}$. 通过 $\mathrm{BiOI}$ 与 $\mathrm{La}(\mathrm{OH})_{3}$ 表面的紧密接触成功构建异 质结, 但 BiOI纳米颗粒未改变 $\mathrm{La}(\mathrm{OH})_{3}$ 纳米棒的形貌. 由TEM和HRTEM图像可见, $\mathrm{La}(\mathrm{OH})_{3}$ 纳米棒的平均长度为 $30-50 \mathrm{~nm}$, 并且在BiOI@ $\mathrm{La}(\mathrm{OH})_{3}$ 异质结中可以清晰看出 $\mathrm{BiOI}$ 和 $\mathrm{La}(\mathrm{OH})_{3}$ 之间紧密接触的界面和晶格间距. $\mathrm{N}_{2}$ 物理吸附结果显示, 随着 BiOI量的增加, BiOI@La $(\mathrm{OH})_{3}$ 异质结的比表面积增加, 但孔体积未现明显变化. UV-Vis DRS结果显示, 引入BiOI后明显促 进了 $\mathrm{La}(\mathrm{OH})_{3}$ 对可见光的吸收能力和利用效率, 从而有利于增强可见光催化活性. 通过理论计算分别得到 $\mathrm{BiOI}$ 和 $\mathrm{La}(\mathrm{OH})_{3}$ 的 价带和导带位置, 表明具有非常匹配的能带结构可以促进BiOI光生电子的有效转移.

可见光催化去除 $\mathrm{NO}$ 测试结果表明, BiOI@La(OH) 3 异质结的光催化活性高达 $50.5 \%$, 明显优于BiOI和 La $(\mathrm{OH})_{3}$. ESR测 试结果显示, $\mathrm{BiOI} @ \mathrm{La}(\mathrm{OH})_{3}$ 异质结可见光催化活性中起主要作用的活性物种是·OH. 结合表征结果, BiOI@ $\mathrm{La}(\mathrm{OH})_{3}$ 纳米棒 异质结可见光催化性能增强的原因主要有三个: (1) BiOI@ $\mathrm{La}(\mathrm{OH})_{3}$ 异质结增大的比表面积有利于反应物和产物在催化剂 表面扩散, 同时可提供更多活性位点参与光催化反应; (2)禁带宽度影响光催化效率, 当 $\mathrm{BiOI}$ 与 $\mathrm{La}(\mathrm{OH})_{3}$ 达到合适比例时, 既 可以促进可见光吸收, 也可以使光生电子具有较强还原能力; (3) BiOI@ $\mathrm{La}(\mathrm{OH})_{3}$ 异质结有利于光生载流子的分离, 从而显 著提高其光催化活性.

关键词: BiOI@La(OH) 3 异质结; 纳米棒; 光催化; 可见光; 一氧化氮去除

收稿日期: 2016-09-28. 接受日期: 2016-11-14. 出版日期: 2017-02-05.

*通讯联系人. 电话/传真: (023)62769785; 电子信箱: dfctbu@126.com

\#通讯联系人. 电子信箱: andyzhangwei@163.com

基金来源：国家重点研发计划(2016YFC0204702); 国家自然科学基金(51478070, 51108487, 21501016); 重庆市高校创新团队 (CXTDG201602014); 重庆市自然科学基金(cstc2016jcyjA0481); 中国科学院青年创新促进会(2015316).

本文的英文电子版由Elsevier出版社在ScienceDirect上出版(http://www.sciencedirect.com/science/journal/18722067). 